\title{
Character Building For Early Childhood: A Case Study for the Teaching of Performing and Fine Arts
}

\author{
Hartono $^{1}$, Yovita Sari ${ }^{2}$ \\ \{hartono_sukorejo@mail.unnes.ac.id ${ }^{1}$ yofita.sari1994@ mail.com ${ }^{2}$ \}
}

Dance, Drama, and Musical Arts Department, Faculty of Language and Arts, Universitas Negeri Semarang ${ }^{1}$

Semesta Bilingual Elementary School ${ }^{2}$

\begin{abstract}
Early childhood is the period of children's growth, physically and mentally. The early building of character is very important in the early childhood period. The effective and efficient process of character building can be done through the education of performing and fine arts. This research aims to review the building of character in Early Childhood Education through the teaching of performing and fine arts. This research employs observation and documentation to collect the data. The data validation used source validation. The analysis of the research used through data reduction, verification, and presentation. The result shows that the character-building triggers children's creativity, rationality, systematicity, critical thinking, and orderliness. The children project the behaviour of honesty, acceptance, tolerance, and responsible. Learning and teaching performing and fine arts potentially develops children's humanist character through the appreciative, expressive, and creative activities, which is implanted in constructive, interactive, and reflective perspective and action. The implication from the research is to show the learning is a way to build character. The character of the children will be better from the teaching of it.
\end{abstract}

Keywords: Early childhood, character, performing and fine arts

\section{Introduction}

According to Fasli, the concern of education in the early childhood in Indonesia is lower than the neighbouring countries, like Singapore, Malaysia, Thailand, Laos, Myanmar, Vietnam, and Brunei Darussalam [1]. The fact shows that the understanding of society to the importance of early childhood is very low. Mostly, the society considers that education is only related to school which is not relevant to early childhood education.

The same thing happens to Nurlaila who says that most people deem that early childhood education can be done by parents with less knowledge regarding early childhood education [2]. Bruner and Donalson say that some most important part of life is obtained from the early period of childhood [3].

Concerning the character of Kindergarten, Semiawan explains that they have the traits of persistence to live in their fantasy [4]. Kindergarten is the period where children unconsciously find their egocentric character. Many experts also remind that Kindergarten is the golden period of intelligence's growth. Blom in Gotama says that four-year-old children have reached 50\%, 
and further, they reach $80 \%$ when they are 8 [5]. Fasli Djalal says the same thing that children's intelligence grow quickly in the early period of their life. Children reach their culmination point while they are 18. Based on Hidayat, children's growth and development need to be taken care since they were a fetus until they are six. The case happens because the investment of human's intelligence is very important [6].

Semiawan explains that human was born from the intelligence sourced from the brain genetically (potentials). The structure of the gene is decided since they have 100 to 200 millions of brain's neuron cell [7]. The neuron handles trillions of information. However, the brain can function depends on the environment of the children. The intelligence is believed to come from the interaction between children's genetics and their environment to grow and develop [8][9][10][11].

From the explanation above, there is an urgency of implanting the character too early childhood education. The effective and efficient media for it are through the teaching of fine and performing arts. The teaching of performing and fine arts can raise children's awareness of their surrounding.

\section{Research Methods}

This research employs a qualitative approach. The method is useful since it is in line with the character and aims of the research, which covers: (1) social process; (2) assumption and hypothesis or theories; (3) verstehen; (4) symbolic (not static); (5) meaning; (6) inductive; and (7) target of the research. The problem in this research is comprehensive and deep which emphasizes the meaning and process of the research.

The setting of natural qualitative research is a place with humans inside. The qualitative research emphasizes on a complex and holistic picture. The research refers to the narrative complex which invites the reader to the plural dimensions of certain problems or issues.

The characteristics of a qualitative research is: (1) identifying problem which tends to explore deeper in certain problem and details on a central certain phenomenon; (2) literature review to play a minor part in suggesting a specific question and justifying the importance of the research; (3) the specification of the research which makes the questions of the research explained in an extensive and wide range of explanation as well as to become the participant; (4) collecting data from the participants, like texts or picture from individuals; (5) analyzing and interpreting data from text and interpretation of text; and (6) reporting and evaluating qualitative research which use flexible structure and emerging evaluation.

The collection of the data was based on a normal situation without any conscious influence. The data were from the text, recording of an interview, and pictures. The source of data in this research are the interviewees, competent people, which are teachers, kindergarten's headmaster, experts of dancing, and relevant interviewees.

The data were collected after the researcher obtained permission from the promotors of the Early Childhood Education department of the Postgraduate program of UNJ, the government, and the kindergarten. The collected data were observation, interview, and documentation.

The analysis of the data in this research used descriptive-qualitative research which is described qualitatively. The analysis of the data was collected interactively through data reduction, data presentation, and conclusion making. 


\section{Findings and Discussion}

Talking about children is relevant to discussing the importance of children's development and growth. The service of education for children is a prioritized program in every country. Through education, people are not only developing their cognitive traits but also their character. Margaret says that the inclusion of dance non-formal education is a platform to give children things to improve their artistic sense in performing and fine arts [12].

The teaching of dance for children is also guiding children to do physical activities throughout the relation of their body parts [13]. To introduce the concept of space-time and energy, dancing encourages children to control their movement and be creative in their moves. The children can develop their imagination and provide reaction from their dance.

The easy dance for children to learn is the dance in which movement copies the movement of animals. As in Holt, dance about the animal is easy for children to follow. The biggest possibility for children to follow easily is the movement of birds, elephants, monkeys, tigers, and deers [14].

Learning changes behaviour. Partini mentions that change is for something hidden to be revealed or to complete something unfinished. Concerning that, Partini explains that the changes from a human can be in the form of understandings, skills, habits, and behaviours [15]. The changes happen through the interaction of individuals to its surrounding.

Learning is an activity which is done to perfect the skills. According to Lulu, the result of motoric behaviour is "psychomotor skills" [16]. The term is related to the understanding, action, and the result to be skilful. Through performing and fine arts, there are some directions to follow. The directions are a line, colour, composition, and surrounding nature. In dancing, the principles are the movement, rhythm, and expression. The freedom of movement and expression in both arts should follow the local norm.

Children need habituation to adapt to the arts. The habituation will be able to improve children's quality of dancing movement. The quality of the movement depends on the pattern which follows certain composition. The other thing which should be concerned with is the costume and the technique of presentation. Ben Suharto explains that the performance of dancing needs the element of characterization which plays the role of the focus point, space, and linear direction. Suharto emphasizes on the material of dancing movement which constructs a dance that performance will have deep image whether for the dancer or the audiences [17].

Arts performance and exhibition project the ideology of its creator. However, not all people can know the meaning. To enjoy the art for the appreciator, there should be an aesthetic awareness for them. The awareness can be included in the performance or exhibition. In the end, the projection will show the physical, rhythmic, expressive, and fineness of the arts [18][19][20][21].

\section{Conclusion}

The building in the Early Childhood through the teaching of arts is in the inclusion of setting and value which triggers the creativity and mindset for children to be rational, systematic, critical, and orderly. Learning about how to dance or how to draw is potentially able to build children's character to be humanist, appreciative, expressive, and creative which can construct children's interactive and reflective mindset 


\section{References}

[1] Fasli Djalal,. 2002. "Pendidikan Anak Dini Usia, Pendidikan yang Mendasar", dalam, Buletin PADU Jurnal Ilmiah Anak Dini Usia (Jakarta: Direktorat Pendidikan Anak Dini Usia, 2002).

[2] Nurlaila N.Q., Mei Tientje dan H., Yul Iskandar,. 2004. PADU Untuk Mengembangkan Multipel Inteligensi. (Jakarta: Dharma Graha Group, 2004).

[3] Dedi Supriadi,. 2002. "Memetakan Kembali Pendekatan Pembelajaran Pendidikan Anak Dini Usia" dalam, Buletin Padu Jurnal Ilmiah Anak Dini Usia. Edisi 03 Desember 2002 (Jakarta : Direktorat PADU, 2002).

[4] Semiawan. Conny R,. 2002. "Penerapan Pembelajaran Pada Anak (Jakarta: PT Indeks, 2008).

[5] Gutama,. 2002. "Pengantar Direktorat PADU" dalam, Buletin PADU Jurnal Ilmiah Anak Dini Usia (Jakarta: Direktorat Pendidikan Anak Dini Usia, 2002).

[6] Hidayat Syarif,. 2002. "Pengembangan Anak Dini Usia Memerlukan keutuhan," dalam, Buletin PADU Jurnal Ilmiah Anak Dini Usia (Jakarta: Direktorat Pendidikan Anak Dini Usia, 2002).

[7] Semiawan, Conny R,. 2002. "Pendidikan Anak Dini Usia Belajar Melalui Bermain", dalam, Buletin PADU Jurnal Ilmiah Anak Dini Usia (Jakarta: Direktorat Pendidikan Anak Dini Usia, 2002).

[8] Akil M Mala,. 2002. "Fungsi strategis Sarana Pembelajaran Dalam Pendidikan Anak Dini Usia," dalam Buletin Padu Jurnal Ilmiah Anak Dini Usia. Edisi 03 Desember 2002, (Jakarta : Direktorat PADU, 2002).

[9] Lily I Rilantono,. 2002. "Konsep pengasuhan dan Pengembangan Anak Dini Usia," dalam Buletin PADU Jurnal Ilmiah Anak Dini Usia (Jakarta: Direktorat Pendidikan Anak Dini Usia, 2002).

[10] Rahmitha P. Soendjojo,. 2002. "Pendidikan Anak Dini Usia Hak Semua Anak," dalam Buletin PADU Jurnal Ilmiah Anak Dini Usia (Jakarta: Direktorat Pendidikan Anak Dini Usia, 2002).

[11] Soemiarti Padmonodewa,. 2002. "Pengembangan Anak Dini Usia, Beberapa Model yang Ada," dalam, Buletin PADU Jurnal Ilmiah Anak Dini Usia (Jakarta: Direktorat Pendidikan Anak Dini Usia, 2002).

[12] Margareth H'Doubler,. 1970. Education through Dance. The Dance Experience Readings in Dance Appreciation. Edited by Myron Howard Nadel and Constance Gwen Nadel (Preacer Publishers. New York. Washington, London, 1970).

[13] Bonnie Bird,. 1981. "Tari sebagai Seni di Lingkungan Akademi" dalam Dance An Art In Academics. Penterjemah Ben Suharto (Yogyakarta : Akademi Seni Tari Indonesia Yogyakarta, 1981).

[14] Claire Holt,. 1967. Art In Indonesia Continuities And Change (Ithaca New York: Cornell University Press, 1967).

[15] Partini,. 1980. Psikologi Pendidikan (Yogyakarta : Studing, 1980).

[16] Lulu E. Sweigard,. 1970. Psychomotor Functian As Correlated With Body Mechanics And Posture. Dalam The Dance Experience Readings in Dance Appreciation. Edited by Myron Howard Nadel and Constance Gwen Nadel (Preacer Publishers. New York. Washington, London, 1970).

[17] Ben Suharto,. 1986. "Bagaimana Mempersiapkan Pementasan Sebuah Drama Tari," dalam Pengetahuan Elemen Tari dan Beberapa Masalah Tari (Jakarta : Direktorat Kesenian, 1986).

[18] Myron Howard Nadel,. 1970. The Prosess of Creating a Dance. The Dance Experience Readings in Dance Appreciation. Edited by Myron Howard Nadel and Constance Gwen Nadel (Preacer Publishers. New York. Washington, London, 1970).

[19] Geoge Beiswanger,. 1970. Chance and Design in Choreography. The Dance Experience Readings in Dance Appreciation. Edited by Myron Howard Nadel and Constance Gwen Nadel (Preacer Publishers. New York. Washington, London. 1970), p.83.

[20] Susanne K. Langer. 1970. Virtual Power. Dalam The Dance Experience Readings in Dance Appreciation. Edited by Myron Howard Nadel and Constance Gwen Nadel (Preacer Publishers. New York. Washington, London, 1970).

[21] Soedarsono, 1986. "Pengantar Pengetahuan dan Komposisi Tari", Pengetahuan Elemen Tari dan Beberapa Masalah Tari (Jakarta : Direktorat Kesenian, 1986). 